\title{
The Influence of Organic and Conventional Food on Human Health
}

\author{
Manal Raden Al Mutiri, Noorah Saleh Al-Sowayan* \\ Department of Biology, College of Science, Qassim University, Buraydah, Saudi Arabia \\ Email: *nsaoiean@qu.edu.sa, ${ }^{\star}$ knaaj1@yahoo.com
}

How to cite this paper: Al Mutiri, M.R. and Al-Sowayan, N.S. (2021) The Influence of Organic and Conventional Food on $\mathrm{Hu}-$ man Health. Food and Nutrition Sciences, 12, 1299-1305.

https://doi.org/10.4236/fns.2021.1212095

Received: November 17, 2021

Accepted: December 24, 2021

Published: December 27, 2021

Copyright $\odot 2021$ by author(s) and Scientific Research Publishing Inc. This work is licensed under the Creative Commons Attribution International License (CC BY 4.0).

http://creativecommons.org/licenses/by/4.0/

\begin{abstract}
Organic food offers immense benefits to consumers as it contains a higher content of nutrients and antioxidants. The benefits of organic food over conventional products have been demonstrated by in-vitro experiments, whereby statistical analysis has shown that both types of food can have equivalent benefits. One of the important disadvantages of conventional food is that it contains heavy metals and also does not contribute toward prevention of cancer in consumers. It is not clear yet if consuming organic food combats obesity; we have attempted to gather some literature to clarify this aspect as well.
\end{abstract}

\section{Keywords}

Organic Food, Consumer Benefits, Cancer Prevention

\section{Introduction}

With increasing awareness in consumers about safe and healthy foods, the demand for organic foods is growing as well [1], which has led to an increase in sales of organic products in markets [2]. The major reason for the popularity of organic foods is the notion that they are the healthier alternative to regular foods [3] [4] [5] [6] [7]. As per common understanding, such food products have higher nutritional value and are free of pesticides and heavy metals [8] [9] [10]. In other cases, people may be interested in organic products because of the promise of environmental sustainability that organic agriculture offers [11] [12] [13]. In this review, we aim to explore the influence of organic foods on health by exploring the differences in nutrient content between organic and conventional foods. We address questions such as: Do organic food consumers enjoy a healthier life according to approved studies? Does consumption of organic foods contribute to reducing the risk of developing cancer?

${ }^{\bar{R}}$ Represent for corresponding author. 


\section{Nutritional Differences}

A number of studies have reported a difference in the nutrient content of organic and conventional food stuffs. A richer nutrient content is generally present in organic food as compared to conventional food. For instance, in their natural states, the level of antioxidants is higher in organic beans than in conventionally grown beans [14]. This conclusion was made by a study that analyzed the differences in total phenolic content in eight types of beans that were cooked to varied extents and under different conditions; phenolic content was reduced in beans of all types after cooking. Similarly, tomato fruits grown in soil treated with organic matter showed higher phenolics and flavonoids than control plants grown in untreated soil. Furthermore, beta-carotene increased in soil that had been treated with chemical fertilizers as compared to untreated soil [15]. Research has also shown organic crops to have the highest concentration of vitamin C, iron, magnesium, and phosphorous. Treatment with organic fertilizers significantly decreases $\mathrm{Cd}, \mathrm{Pb}$, and As in tea leaves [16] [17] [18]. Conventional crops contain high levels of heavy metals, which pose a threat to people's lives. In an in-vitro study, the biochemical properties of organic foods revealed them to have higher activity of antioxidants and antimutagenic agents as compared to conventional foods [19].

The major nutritional differences are summarized in Table 1 below [19].

\section{Gap of Previous Studies and Research Significance}

Despite the growing research interest in organic food and its health effects on the population, there is still a lack of studies that have applied reliable statistical tests to compare health effects of organic and conventional food in relation to the main criteria [20]. The significance of the present research refers to identifying the major long-term health effects, including the risks of serious diseases such as cancer in people consuming organic and conventional food respectively. On this basis, better-supported nutritional recommendations can be formulated.

Table 1. Nutritional differences between organic and conventional food.

\begin{tabular}{ccc}
\hline Criterion & Organic Food & $\begin{array}{c}\text { Conventional } \\
\text { Food }\end{array}$ \\
\hline $\begin{array}{c}\text { Antioxidants' availability } \\
\text { Phenolics and } \\
\text { flavonoids concentration } \\
\text { Beta-carotene levels } \\
\text { Concentration of vitamin C, iron, } \\
\text { magnesium, and phosphorous }\end{array}$ & High & Low \\
than conventional food $)$ & High \\
Level of heavy metals & High & Low \\
\hline
\end{tabular}




\section{Organic Food and a Healthy Lifestyle}

The risk of obesity is reported to decrease by $31 \%$ in individuals who consume organic foods as compared to in individuals, who consume conventional foods. A strong correlation was observed to exist between reduced risk of obesity and introduction of organic foods in diet [21]. Consumers of organic foods also exhibit higher levels of fitness [12] [20] [22] [23]. In addition to obesity, the levels of physical activity as well as the balance of carbohydrates, protein, vitamins, and minerals were also included in the parameters being evaluated [19].

\section{Organic Food and Cancer}

Increased consumption of organic foods has been associated with a decreased risk of developing non-Hodgkins lymphoma (NHL). Similarly, it has also been established that there is a reduced risk of breast cancer and soft tissue sarcoma in people with preferential consumption of organic food [24]. Preference for organic food and frequency of consumption was measured in terms of the individuals' eating organic food only sometimes, often, or never. Another study based on a large cohort of 68,946 participants observed that a higher organic food score (that reflected a higher frequency of organic food consumption) was associated with a decreased risk of developing NHL and postmenopausal breast cancer [25]. At the same time, no association was detected for other types of cancer [25].

\section{Accessing Reliable Data on Organic and Conventional Food}

The recent and reliable data on organic and nutritional food as well as their health effects can be accessed from corresponding peer-reviewed journal articles [19]. In addition, official websites and publications of government agencies and non-government organizations may provide the relevant statistics and explanations that may inform better-supported decisions to be made by a concrete individual.

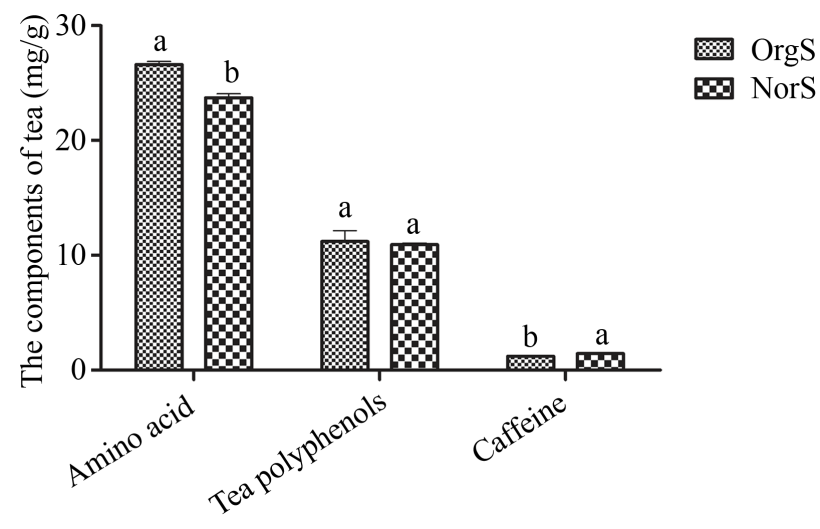

Figure 1. Amino acids, polyphenols, and caffeine contents of tea under treatment with organic (OrgS) or chemical (NorS) fertilizer. Columns with different letters indicate statistically significant difference (LSD test, $\mathrm{p}<0.05)$ [18]. 
Table 2. Pearson's correlation coefficient for total polyphenol content and antioxidant capacity of organic and conventionally grown beans.

\begin{tabular}{cc}
\hline Pearson's correlation coefficient $(r)$ & Parameter \\
0.840 & DPPH radical scavenging activity \\
0.867 & ABTS radical scavenging activity \\
0.774 & FRAP activity \\
\hline
\end{tabular}

DPPH: 2,2-diphenyl-1-picrylhydrazyl, ABTS: 2,2'-Azino-bis(3-ethylbenzthiazoline-6-sulfonic acid); FRAP: Fluorescence recovery after photobleaching.

Table 3. Analysis of variance (ANOVA) of means square [MS $(\operatorname{Pr}>F)$ for photochemical compounds [26].

\begin{tabular}{cccccc}
\hline Source & $\begin{array}{c}\text { Total } \\
\text { phenols }\end{array}$ & $\begin{array}{c}\text { Total } \\
\text { flavonoids }\end{array}$ & $\begin{array}{c}\text { DPPH } \\
\text { scavenging assay }\end{array}$ & $\begin{array}{r}\text { FRAP } \\
\text { assay }\end{array}$ & $\begin{array}{c}\text { Cyanogenic } \\
\text { glycoside }\end{array}$ \\
\hline Fertilizer & $259.23^{*}$ & $53.76^{* *}$ & $502.98^{* *}$ & $672.65^{* *}$ & $0.022^{\star}$ \\
Variety & $134.48^{*}$ & $5.44^{*}$ & $494.02^{* *}$ & 0.37 & 0.002 \\
F $\times \mathrm{V}$ & $56.91^{*}$ & $17.43^{* *}$ & $45.34^{* *}$ & $13.31^{*}$ & 0.001 \\
$\mathrm{CV}(\%)$ & 2.91 & 2.70 & 3.68 & 3.00 & 9.02 \\
\hline
\end{tabular}

${ }^{*}$ means significant at $\mathrm{p}<0.01$ and ${ }^{\star}$ means significant at $\mathrm{p}<0.05$.

\section{Future Prospects}

Currently, numerous statistical studies have compared phenolic and flavonoid compounds in organic and conventional crops, both of which are established to be highly correlated with antioxidant activity [27] [28]. Table 2 and Table 3, as well as Figure 1, present a summary of phenolic content in conventional and organic crop production. It was reported by the authors of this information that the difference in phenolic content in organic and conventional crops was not statistically significant. However, when the same experiment was performed in laboratory settings, statistically significant differences were observed with organic crops having higher flavonoid content.

Given the varying results from research, it is not possible to conclude with confidence as to which organic foods contribute to reducing the risk of cancer. Regardless, the variability in results signifies its importance for health, and more clinical studies comparing organic and conventional foods will be immensely valuable to clarify this aspect. From our perspective, more studies will help elaborate the reasons working behind the lesser nutritional value of conventional products as compared to organic foods. A predominant idea in this regard is that the use of fertilizers may be the major cause for reduced nutritional benefits from conventional foods [19]; however, much research needs to be done to evaluate this hypothesis on both laboratory and field scales. Future research should consider the influence that the two different kinds of meals have on people with the same health conditions, sports practices, lifestyle, age, and gender. Such research would help solve the debate on whether consumers of organic foods are 
truly making better and healthier food choices that reflect positively on individuals' health [29] [30] [31] [32].

\section{Conflicts of Interest}

The authors declare no conflicts of interest regarding the publication of this paper.

\section{References}

[1] Willer, H. and Lernoud, J. (2019) The World of Organic Agriculture. Statistics and Emerging Trends 2019. Research Institute of Organic Agriculture FiBL and IFOAM Organics International, $336 \mathrm{p}$.

[2] Golijan, J. and Dimitrijević, B. (2018) Global Organic Food Market. Acta Agriculturae Serbica, 23, 125-140. https://doi.org/10.5937/AASer1846125G

[3] Magnusson, M.K., Arvola, A., Hursti, U.K.K., Åberg, L. and Sjödén, P.O. (2003) Choice of Organic Foods Is Related to Perceived Consequences for Human Health and to Environmentally Friendly Behaviour. Appetite, 40, 109-117. https://doi.org/10.1016/S0195-6663(03)00002-3

[4] Hughner, R.S., McDonagh, P., Prothero, A., Shultz, C.J. and Stanton, J. (2007) Who Are Organic Food Consumers? A Compilation and Review of Why People Purchase Organic Food. Journal of Consumer Behaviour, 6, 94-110. https://doi.org/10.1002/cb.210

[5] Michaelidou, N. and Hassan, L.M. (2008) The Role of Health Consciousness, Food Safety Concern and Ethical Identity on Attitudes and Intentions towards Organic Food. International Journal of Consumer Studies, 32, 163-170. https://doi.org/10.1111/j.1470-6431.2007.00619.x

[6] Van Huylenbroek, G., Mondelaers, K., Aertsens, J., Aertsens, J., Verbeke, W., Mondelaers, K. and Van Huylenbroeck, G. (2009) Personal Determinants of Organic Food Consumption: A Review. British Food Journal, 111, 1140-1167.

[7] Hoefkens, C., Verbeke, W., Aertsens, J., Mondelaers, K. and Van Camp, J. (2009) The Nutritional and Toxicological Value of Organic Vegetables: Consumer Perception versus Scientific Evidence. British Food Journal, 111, 1062-1077. https://doi.org/10.1108/00070700920992916

[8] Lairon, D. and Huber, M. (2014) Food Quality and Possible Positive Health Effects of Organic Products. In: Bellon, S. and Penvern, S., Eds., Organic Farming, Prototype for Sustainable Agricultures, Springer, Dordrecht, 295-312. https://doi.org/10.1007/978-94-007-7927-3_16

[9] Rembiałkowska, E. (2007) Quality of Plant Products from Organic Agriculture. Journal of the Science of Food and Agriculture, 87, 2757-2762.

https://doi.org/10.1002/jsfa.3000

[10] Barański, M., Średnicka-Tober, D., Volakakis, N., Seal, C., Sanderson, R., Stewart, G.B., Benbrook, C., Biavati, B., Markellou, E., Giotis, C. and Gromadzka-Ostrowska, J. (2014) Higher Antioxidant and Lower Cadmium Concentrations and Lower Incidence of Pesticide Residues in Organically Grown Crops: A Systematic Literature Review and Meta-Analyses. British Journal of Nutrition, 112, 794-811. https://doi.org/10.1017/S0007114514001366

[11] Ugarte, C.M., Kwon, H., Andrews, S.S. and Wander, M.M. (2014) A Meta-Analysis of Soil Organic Matter Response to Soil Management Practices: An Approach to Evaluate Conservation Indicators. Journal of Soil and Water Conservation, 69, 422-430. https://doi.org/10.2489/jswc.69.5.422 
[12] Mondelaers, K., Aertsens, J. and Van Huylenbroeck, G. (2009) A Meta-Analysis of the Differences in Environmental Impacts between Organic and Conventional Farming. British Food Journal, 111, 1098-1119. https://doi.org/10.1108/00070700910992925

[13] Tuck, S.L., Winqvist, C., Mota, F., Ahnström, J., Turnbull, L.A. and Bengtsson, J. (2014) Land-Use Intensity and the Effects of Organic Farming on Biodiversity: A Hierarchical Meta-Analysis. Journal of Applied Ecology, 51, 746-755. https://doi.org/10.1111/1365-2664.12219

[14] Mastura, H.Y., Hasnah, H. and Dang, T.N. (2017) Total Phenolic Content and Antioxidant Capacity of Beans: Organic vs Inorganic. International Food Research Journal, 24, 510-517.

[15] Aina, O.E., Amoo, S.O., Mugivhisa, L.L. and Olowoyo, J.O. (2019) Effect of Organic and Inorganic Sources of Nutrients on the Bioactive Compounds and Antioxidant Activity of Tomato. Applied Ecology and Environmental Research, 17, 3681-3694. https://doi.org/10.15666/aeer/1702_36813694

[16] Worthington, V. (2001) Nutritional Quality of Organic versus Conventional Fruits, Vegetables, and Grains. The Journal of Alternative \& Complementary Medicine, 7, 161-173. https://doi.org/10.1089/107555301750164244

[17] Tchounwou, P.B., Yedjou, C.G., Patlolla, A.K. and Sutton, D.J. (2012) Heavy Metal Toxicity and the Environment. In: Luch, A., Ed., Molecular, Clinical and Environmental Toxicology. Experientia Supplementum, Springer, Basel, 133-164. https://doi.org/10.1007/978-3-7643-8340-4_6

[18] Lin, W., Lin, M., Zhou, H., Wu, H., Li, Z. and Lin, W. (2019) The Effects of Chemical and Organic Fertilizer Usage on Rhizosphere Soil in Tea Orchards. PloS ONE, 14, e0217018. https://doi.org/10.1371/journal.pone.0217018

[19] Huber, M., Rembiałkowska, E., Średnicka, D., Bügel, S. and Van De Vijver, L.P.L. (2011) Organic Food and Impact on Human Health: Assessing the Status Quo and Prospects of Research. NJAS- Wageningen Journal of Life Sciences, 58, 103-109. https://doi.org/10.1016/j.njas.2011.01.004

[20] Gomiero, T., Paoletti, M.G. and Pimentel, D. (2008) Energy and Environmental Issues in Organic and Conventional Agriculture. Critical Reviews in Plant Sciences, 27, 239-254. https://doi.org/10.1080/07352680802225456

[21] Kesse-Guyot, E., Baudry, J., Assmann, K.E., Galan, P., Hercberg, S. and Lairon, D. (2017) Prospective Association between Consumption Frequency of Organic Food and Body Weight Change, Risk of Overweight or Obesity: Results from the NutriNet-Santé Study. British Journal of Nutrition, 117, 325-334. https://doi.org/10.1017/S0007114517000058

[22] Baudry, J., Allès, B., Péneau, S., Touvier, M., Méjean, C., Hercberg, S., Galan, P., Lairon, D. and Kesse-Guyot, E. (2017) Dietary Intakes and Diet Quality According to Levels of Organic Food Consumption by French Adults: Cross-Sectional Findings from the NutriNet-Santé Cohort Study. Public Health Nutrition, 20, 638-648. https://doi.org/10.1017/S1368980016002718

[23] Tuomisto, H.L., Hodge, I.D., Riordan, P. and Macdonald, D.W. (2012) Does Organic Farming Reduce Environmental Impacts?-A Meta-Analysis of European Research. Journal of Environmental Management, 112, 309-320.

https://doi.org/10.1016/j.jenvman.2012.08.018

[24] Bradbury, K.E., Balkwill, A., Spencer, E.A., Roddam, A.W., Reeves, G.K., Green, J., Key, T.J., Beral, V. and Pirie, K. (2014) Organic Food Consumption and the Incidence of Cancer in a Large Prospective Study of Women in the United Kingdom. British Journal Cancer, 110, 2321-2326. https://doi.org/10.1038/bjc.2014.148 
[25] Baudry, J., Assmann, K.E., Touvier, M., Allès, B., Seconda, L., Latino-Martel, P., Ezzedine, K., Galan, P., Hercberg, S., Lairon, D. and Kesse-Guyot, E. (2018) Association of Frequency of Organic Food Consumption with Cancer Risk: Findings from the NutriNet-Santé Prospective Cohort Study. JAMA Internal Medicine, 178, 1597-1606. https://doi.org/10.1001/jamainternmed.2018.4357

[26] Nur, F.O., Siti, A.H. and Umi, K.Y. (2013) Comparative Evaluation of Organic and Inorganic Fertilizers on Total Phenolic, Total Flavonoid, Antioxidant Activity and Cyanogenic Glycosides in Cassava (Manihot esculenta). African Journal of Biotechnology, 12, 2414-2421.

[27] Karakaya, S. (2004) Bioavailability of Phenolic Compounds. Critical Reviews in Food Science and Nutrition, 44, 453-464.

https://doi.org/10.1080/10408690490886683

[28] Breuer, G., Lamers, P.P., Martens, D.E., Draaisma, R.B. and Wijffels, R.H. (2012) The Impact of Nitrogen Starvation on the Dynamics of Triacylglycerol Accumulation in Nine Microalgae Strains. Bioresource Technology, 124, 217-226. https://doi.org/10.1016/j.biortech.2012.08.003

[29] Goetzke, B., Nitzko, S. and Spiller, A. (2014) Consumption of Organic and Functional Food. A Matter of Well-Being and Health? Appetite, 77, 96-105. https://doi.org/10.1016/j.appet.2014.02.012

[30] Eisinger-Watzl, M., Wittig, F., Heuer, T. and Hoffmann, I. (2015) Customers Purchasing Organic Food-Do They Live Healthier? Results of the German National Nutrition Survey II. European Journal of Nutrition \& Food Safety, 5, 59-71.

[31] Kesse-Guyot, E., Péneau, S., Mejean, C., de Edelenyi, F.S., Galan, P., Hercberg, S. and Lairon, D. (2013) Profiles of Organic Food Consumers in a Large Sample of French Adults: Results from the Nutrinet-Santé Cohort Study. PloS ONE, 8, e76998. https://doi.org/10.1371/journal.pone.0076998

[32] Pelletier, J.E., Laska, M.N., Neumark-Sztainer, D. and Story, M. (2013) Positive Attitudes toward Organic, Local, and Sustainable Foods Are Associated with Higher Dietary Quality among Young Adults. Journal of the Academy of Nutrition and Dietetics, 113, 127-132. https://doi.org/10.1016/j.jand.2012.08.021 